\title{
Performance Assessment of Local Government Organizations on Flood Disaster Prevention and Preparedness in Gunung Mas Regency
}

Eris Oktani Maya Sintha ${ }^{1}$, Budi Suryadi ${ }^{2^{*}}$, M. Riduansyah Syafari ${ }^{3}$

${ }^{1}$ Master of Government Science Students, Lambung Mangkurat University, Indonesia

${ }^{2},{ }^{3}$ Faculty of Social Science and Political Science, Lambung Mangkurat University, Indonesia

DOI: $10.36348 /$ sijlcj.2020.v03i12.006

| Received: 03.12.2020 | Accepted: 15.12.2020 | Published: 18.12.2020

*Corresponding author: Budi Suryadi

\section{Abstract}

Performance assessment requires the demands of accountability, implementation of the control functions and development needs of local government organizations in the handling and prevention of floods in the region. The method used in this research is qualitative method. Data collection techniques are carried out using participatory observations, interviews and documentation studies. Data analysis is done with descriptive techniques through three flow of activities that are one unity, namely: data reduction, data presentation and conclusion drawing. The results showed the performance assessment of the Gunung Mas District Disaster Management Agency on the prevention and preparedness of flood disasters from the aspect of understanding the auth and aspects of work accuracy tends to be many activities in the field of disaster prevention and preparedness carried out and aspects of innovation, work speed and cooperation are still minimal socialization of disaster-aware culture through simulation in the field and the lack of innovation in the field of disaster prevention and preparedness.

Keywords: Performance assessment, local government organization, flood prevention.

Copyright (C) 2020 The Author(s): This is an open-access article distributed under the terms of the Creative Commons Attribution 4.0 International License (CC BY-NC 4.0) which permits unrestricted use, distribution, and reproduction in any medium for non-commercial use provided the original author and source are credited.

\section{INTRODUCTION}

Indonesia is a region prone to various disasters, including natural disasters. Natural disasters are natural phenomena that can cause environmental damage. Natural disasters that occur due to the exploitation of natural resources such as forests, land and water in excess and due to global climate change has resulted in more and more critical land, in addition the impact will change the use of water so that it can lead to floods, landslides, droughts, forest and land fires and increased erosion rates.

One of the natural phenomena that cause great losses and always threaten the region in Indonesia is the flood disaster. Flooding is an ordinary natural phenomenon, but it will be a very detrimental thing if it threatens human survival so that it requires an effort in terms of flood disaster management.

The Central Government has made a public policy in disaster management efforts, namely by establishing a national body from the central to regional levels that deals with disaster management, namely the National Disaster Management Agency. The National Disaster Management Agency was established based on Presidential Regulation No. 8 of 2008 and is the realization of Article 10 paragraph (1) of Law No. 24 of 2007 governing disaster management.

One of the natural phenomena that cause great losses and always threaten the region in Indonesia is the flood disaster. Flooding is an ordinary natural phenomenon, but it will be a very detrimental thing if it threatens human survival so that it requires an effort in terms of flood disaster management. Natural disasters that often occur in the area of Gunung Mas Regency is a flood disaster.

There are several problems in the performance assessment of the Gunung Mas District Disaster Management Agency in the field of disaster prevention and preparedness, namely: 1. The limitations of effective information and communication networks in the delivery of disaster information to the community; 2. The lack of effective disaster awareness, community socialization activities carried out by the Gunung Mas District Disaster Management Agency, which only delivers material without being followed up with practices concerning community preparedness to deal with disasters; 3. The Disaster Management Plan in Gunung Mas Regency has not been prepared; 4. Human 
resources (HR) apparatus at the Gunung Mas District Disaster Management Agency is limited.

That the characteristics of a high-performancebased organization are to have a clear mission, set the results to be achieved and focus on achieving these successes, empowering its employees, motivating individuals in the organization to succeed, being flexible and always able to adjust to new conditions, always competing to improve performance, always improving work procedures in order to meet the needs of customers or society, always communicate with stakeholders [1].

Detail the objectives of performance assessment that is to improve or improve organizational performance through improving human resource performance is improving mutual understanding between employees about performance requirements and record and acknowledge the work of an employee so that he/she is motivated to do better or equal to his/her previous achievements [2].

\section{RESEARCH METHODS}

The research approach used is qualitative approach that is an effort to reveal a problem, condition as it happens so that the research reveals the facts and provides an objective picture of the actual state of the object studied. This type of research is qualitative to describe the phenomenon that occurred in the Gunung Mas District Disaster Management Agency, especially performance in the field of flood prevention and preparedness.

Research on the performance assessment of the Gunung Mas District Disaster Management Agency in the field of disaster prevention and preparedness requires competent research informants and have knowledge directly related to the problems studied so that the data and information obtained are accurate and reliable.

To obtain the data the authors presented the following data collection techniques, namely participatory observations through careful direct observation in the field, interviews used to obtain primary data through unstructured interview techniques, and documentation studies in the form of study of regulatory documents related to the main tasks and functions of the Regional Disaster Management Agency.

Data analysis as a process of systematically searching and compiling data obtained from interviews, field records and documentation so that it is easy to understand and its findings can be informed to others [3] Data analysis using interactive data collection, data presentation, data reduction and verification [4].

\section{RESULT AND DISCUSSION}

Performance assessment is not a control or supervision activity and nor is it looking for wrongdoing to impose sanctions or penalties. Performance assessment activities are focused on expressing the shortcomings in working to be improved and excess work to be developed, so that every employee knows the level of efficiency and effectiveness and his contribution in carrying out his work to achieve the objectives of the organization. Therefore, the aspects that are assessed must be in accordance with what should be done as contained in the analysis of the work in the form of job descriptions.

The assessment of employees as a systematic evaluation of the work of employees and potentials that can be developed [5]. A process used by the leadership to determine whether an employee is doing his or her job in accordance with his or her responsibilities called a work performance assessment [6].

Performance assessment instruments are tools that facilitate organizations to more easily achieve their goals. Performance assessment is also a key factor in developing an organization effectively and efficiently due to better policies or programs for human resources in the organization with the aim of improving or improving performance.

Performance assessment is a key factor in developing an organization effectively and efficiently, due to better policies or programs on human resources in the organization. Individual performance assessment is very useful for the dynamics of overall organizational growth, through such assessments will be able to know the actual condition of how employees perform.

Based on Gunung Mas District Regulation Number 2 Year 2012 concerning the implementation of disaster management stated in article 6 states that the implementation of disaster management in the predisaster stage in the form of early warning activities, prevention, taming and community preparedness and local government apparat aimed at minimizing the onset of human casualties, property losses and environmental damage.

The implementation of disaster management in the pre-disaster stage includes in the situation of no disaster or in a situation where there is a potential for disaster. Implementation of disaster management in disaster-prone situations include disaster management planning, preparation of potential community protection and task forces that are ready to be moved in disaster management, preparation of disaster-prone maps and informing the community, provision of posts and field post infrastructure that can be used at any time as well as education and training.

Implementation of disaster management in situations where disasters are potential, including preparedness activities carried out to improve the preparedness of people living in disaster-prone areas, 
early warning is carried out to take swift and appropriate action in order to reduce the risk of disaster and disaster mitigation is carried out to reduce the risks and impacts caused by disasters on communities in disaster-prone areas.

Performance assessment of the Regional Disaster Management Agency on the prevention and preparedness for flood disasters in Gunung Mas Regency includes several aspects, as follows, namely:

First, an understanding of tasks and function. Based on the implementation of the main duties and functions of the Gunung Mas Regency Disaster Management Agency, it is based on Law No. 24 of 2007 on Disaster Management and Regional Regulation No. 9 of 2013 on Disaster Management. Gunung Mas Regency Disaster Management Agency was formed in order to provide protection to people's lives and livelihoods for disasters so that disaster management efforts can be implemented systematically, planned, coordinated and integrated. The findings in the field show that the Gunung Mas District Disaster Management Agency, especially in the field of disaster prevention and preparedness, already understands its main duties and functions so that it carries out its duties in accordance with what is its responsibility.

The understanding of this task and function includes: 1. The establishment of disaster awareness culture through the formation of 11 community groups in 9 sub-districts; 2. Maintained firefighting equipment; 3. Implementation of disaster hazard information distribution; 4. Implementation of coordination meetings between agencies; 5. Implementation of the determination of forest and land fire control posts; 6 . Implementation of development of forest and land fire control facilities and infrastructure; 7. Implementation of the improvement of the Community Care for Fire partnership system; 8. Establishment and development of forest and land fire control brigades; and 9. Implementation of disaster prevention counseling.

His tendency shows that the field of disaster prevention and preparedness has carried out activities in accordance with its main duties and functions. Based on the documentation, study that the field of disaster prevention and preparedness has done the preparation of disaster-prone maps, the preparation of fixed procedures for disaster management and socialization activities of disaster-conscious communities. Although there are still activities that have not been implemented such as the preparation of the Gunung Mas Regency Disaster Management Plan and the preparation of contingency plans. Disaster aware cultural socialization activities that have been carried out are still only in the form of material delivery without being accompanied by simulation activities or practices in the field. In the future, the Gunung Mas Regency Disaster Management Agency will strive to do so.
Second, innovation. Innovations carried out by the field of prevention and preparedness of the Regional Disaster Management Agency Gunung Mas regency is still not maximal in terms of carrying out its main duties and functions. So far, the innovations carried out by the Gunung Mas District Disaster Management Agency to achieve the desired performance are still limited to providing socialization to the community about disaster-aware culture without simulation so that the community is easily involved in disaster management, and especially once the community is ready to be prepared if the flood disaster occurs.

There is still no disaster data and information system that is appropriate in carrying out its main tasks and functions, where the data of disaster events has not been presented properly. Relevant to this according to Fadel the flexibility to innovate is very important in improving performance [7].

Disaster awareness, cultural development activities are one of the disaster prevention activities in terms of disaster risk reduction so that the risk of disasters that may occur in the Gunung Mas regency can be minimized. This was made clear, disaster risk reduction includes the introduction and monitoring of disaster risks, participatory planning of disaster management, development of disaster aware culture, increased commitment to disaster management actors and the application of physical, nonphysical, and disaster management arrangements carried out to reduce adverse impacts that may arise and be carried out in non-disaster situations [8].

Third, the speed of work. The performance of the Gunung Mas Regency Disaster Management Agency is very necessary to be supported by the existence of complete and adequate facilities and infrastructure so that the Gunung Mas Regency Disaster Management Agency can carry out its duties and functions properly. If the facilities and infrastructure are adequate, of course, the Regional Disaster Management Agency of Gunung Mas Regency will be faster in carrying out its duties in the field.

Quickly and appropriately is one of the principles in disaster management, that disaster management must be implemented quickly and appropriately in accordance with the demands of the situation and must follow the existing working methods. Fast and precisely a job are also supported by the existence of adequate facilities and infrastructure. In addition, in order to quickly complete a job is also related to employee discipline. The education and training of employees are also very supportive in the completion of a job.

Based on the Performance Report of the Gunung Mas District Disaster Management Agency, facilities and infrastructure owned by the Gunung Mas 
District Disaster Management Agency to support its performance are 1 unit of firefighting cars, 1 unit of field kitchen car, 1 unit of command car, 2 units of pick up cars, 1 unit of speed boat, 1 unit of rubber boat 1 tank car unit, 4 units of operational motorcycles.

The field of disaster prevention and preparedness has not been able to complete the work within the specified time, although judging from the discipline aspect that some employees have been disciplined within the time of entering working hours. Gunung Mas District Disaster Management Agency already has a disaster-prone map so that it can help speed in completing work and can help the community to be alert to disaster-prone areas.

There are constraints in the Regional Disaster Management Agency Gunung Mas Regency, such as the lack of facilities and parasarana, lack of coordination between government agencies and the lack of budget to support the rapid completion of a job, especially for flood disaster management, resulting in the Regional Disaster Management Agency Gunung Mas regency is not timely in carrying out its main duties and functions. Gunung Mas District Disaster Management Agency already has Standard Operational Procedures in each field so that in the implementation of work has followed the existing SOP. This is in accordance with Popovich's opinion (1998) that organizations should always improve work procedures for improving the quality of work.

Handling the problem of assistance for flood victims in The Village of Tampang Tumbang Anjir is still running slowly. During this time in the event of a flood disaster, logistical assistance is still waiting for assistance from the Disaster Management and Fire Management Agency of Central Kalimantan Province and the National Disaster Management Agency. Gunung Mas Regency Disaster Management Agency is still not able to procure its own logistics as a buffer stock in case of disaster in the Gunung Mas Regency area due to budget constraints owned by the Gunung Mas Regency Disaster Management Agency.

Fourth, the accuracy of the Work. Gunung Mas District Disaster Management Agency, both in the implementation and completion of tasks, has been disciplined and thorough in the implementation of its duties. But there are still many obstacles faced by the Regional Disaster Management Agency Gunung Mas in carrying out its duties and functions are the lack of coordination with relevant agencies, the lack of human resources plus inadequate facilities and infrastructure.

The existence of some obstacles eventually slowed down and affected the accuracy of the work of the Regional Disaster Management Agency Gunung Mas it. Employees of the Gunung Mas District Disaster Management Agency have been quite disciplined in terms of working hours and working hours. Training problems for employees in the Gunung Mas District Disaster Management Agency have already conducted disaster emergency response task force training, tent installation action plan activities and kitchen car operations.

The limited budget given to the Gunung Mas Regency Disaster Management Agency is also a fundamental issue to be able to provide optimal services to the community. In addition, the problem is human resources both in terms of quality and quantity still need improvement to get optimal performance in providing services.

Fifth, cooperation. That the Gunung Mas Regency Disaster Management Agency cooperates with other government agencies such as social services, health services, TNI /Polri, volunteers and other agencies in terms of disaster management. But so far cooperation between government agencies in the region has not provided a response and response because they think that the disaster problem is only handled by BPBD alone, so that there is less cooperation and better coordination between government agencies in the region.

This is not in accordance with the opinion of Nurjanah, one of the principles of disaster management is a partnership involving various parties in a balanced manner and the need for coordination and integration that is intended as a disaster management effort based on good coordination and mutual support and implemented in an integrated manner based on good cooperation and mutual support.

Teamwork among bureaucratic apparatus has not become a culture in bureaucracy. The view and thinking that arises from each apparatus is to only do tasks that become its own obligations, without the need to help the work of other apparatus.

\section{CONCLUSION}

Based on the description in the previous chapter, can be formulated some conclusions as follows: 1. Assessment of the performance of the Regional Disaster Management Agency in the prevention and preparedness for flood disasters in Gunung Mas Regency on aspects of understanding the tasks and functions, and aspects of work accuracy tend to be many in the field of disaster prevention and preparedness activities; 2. Assessment of the performance of the Regional Disaster Management Agency in the prevention and preparedness for flood disasters in Gunung Mas Regency on aspects of innovation, speed of work and cooperation tends to be minimal in socialization about disaster-aware culture and lack of innovation in the field of disaster prevention and preparedness. 


\section{REFERENCES}

1. Popovich, G. M. (1998). Creating-Performance Government Organization, Michigan: Wiley.

2. Mangkunegara, A. P. (2005). Evaluasi Kinerja SDM. Bandung: PT Refika Aditama.

3. Moleong, L. (2013). Metode Penelitian Kualitatif: Edisi Revisi. Bandung: PT Remaja Rosdakarya

4. Miles, M. B., \& Huberman. (1984). A Qualitative Data Analysis: A Sourcebook of New Method. London: Sage Publications Inc.
5. Sikula, A. E. (1981). Training dan Pengembangan Tenaga Kerja. Jakarta: Pustaka Binaman.

6. Megginson, L. C., Mosley, D. C., Pietri, P.H. (1989). Management: Concepts and Applications. New York: Harper and Row.

7. Fadel, M. (2009). Reinventing Local Government: Pengalaman dari Daerah. Jakarta: PT Elex Media Computindo.

8. Nurjanah. (2013). Manajemen Bencana. Bandung: Alfabeta. 